\title{
Toward Making Social Media Effective in our Classrooms: A 9-Point Method
}

\author{
https://doi.org/10.3991/ijim.v12i4.9201 \\ Muhammad B. Nawaila( $\left.{ }^{\square}\right)$,Sezer Kanbul, Huseyin Uzunboylu \\ Near East University, Lefkosia, Cyprus \\ mbnawaila@gmail.com
}

\begin{abstract}
There is absolutely no doubt that the social media have advanced into Tertiary Institution, but Instructors mostly use social media for personal reasons. This research explores the social media world and how teachers use social media in their classes, by conducting a mixed method research where open-ended questionnaires were given to lecturers and interviews were further conducted with some selected lecturers in order to assess how they use social media in their classes. The information collected was organized and used to teach part of a class in multimedia development course where they serve as the control group. A close-ended questionnaire was then administered to the control group at the end of the course and their level of satisfaction recorded. The remaining part of the class forms the experimental group and was taught using the researcher's 9-point method of applying social media in the classroom; using the same questionnaire, their satisfaction level was recorded. The data collected on the student's satisfaction level was analyzed using SPSS software version 20 and the result was that most of the teachers employ the social media for personal use, and that older teachers use less social media in education than their younger counterparts. High social media usage was found among both the teachers and students so also was the time spent on social media and a significant increase in satisfaction level was noticed among students of the experimental group.
\end{abstract}

Keywords-Social media, learning, teaching, methodology, multimedia

\section{Introduction}

Over the last couple of years, the discovery of the Internet has immensely affected both professional and personal lives of human beings with almost 4 billion users and an annual increase of over $10 \%$ [1], providing them with huge opportunities for sourcing information, acquiring and giving out knowledge and also achieving one's learning objectives [2]. If the internet were to be a family, then the favourite and most loved child would certainly have been the "social media".

Social media is a phrase coined to mean the collection of online corresponding mediums committed to general input, content-sharing, synergy and collaboration, it was formed by the use of "social" which means interaction with different individuals 
by providing or collecting information and "media" which means an instrument for correspondence like the internet, when assembled social media implies internet based communication devices that enables individuals to relate with each other by giving and receiving information and the basic characteristics of social media are, useraccount, information/profile pages, followers or friends, newsfeeds, notification, updating, like or comment, review, rating or voting [3]. With over one third of the world using social media [1] using social media in teaching and researching has become imperative.

Social media appears in various forms, among which are chatting application, image-sharing platforms, social gaming, blogs and micro blogs and lastly social networks [32], which is a modern term used to extensively characterize various forms of networking tools that stress the social parts of the internet as a medium for correspondence, collaboration and innovative expression, and is frequently compatible with the terms Web 2.0 and social programming[4].

As indicated by Smith [5] Teaching is the method of attending to individuals needs experience and feeling, and making particular interventions to aid them in learning specific thing, it is performing a specific moral assignment or exercises the goal of which is to initiate learning. The basic aim of teaching at any level of education is to get a principal change in the learner [6]. To encourage the procedure of the transmission of knowledge, instructors ought to apply proper instructing techniques that best suit particular goals. Despite the fact that learning is a procedure that includes examining, creating, thinking and utilizing suitable systems to tackle issues, instructors ought to understand that it turns out to be more successful if the students are encouraged to deliver, instead of just made to memories certain information. Students get a greater comprehension of the fundamental ideas better when they are part of the problem solving team while undertaking class exercises. [7] realize that without new ways of teaching that link to the learning needs of the students, students will perform ineffectively and are probably going to drop out of school.

\section{Problem statement}

The basic role of teaching at any level is to provide the learner with certain changes [6]. To encourage learning transmission procedures, instructors ought to apply appropriate instructional techniques that best fits particular purposes. Most instructors nowadays apply student-centered method to advocate concern, systematic research, critical thinking and satisfaction within students [8]. The instruction methodology is viewed to be more successful since the discharge of knowledge is not centered all around the teacher passing it to the students [9].The procedure arouses goal-oriented behavior with in students, consequently, the technique is extremely good in enhancing students achievements [10].

Fill [11] stated that the best dialogue happens when individuals have been reached from their favourite means, likewise utilizing channels that students incline toward will be viable to bolster their learning processes. This shows that digital age students need a dynamic learning background that is social, participatory and upheld by rich 
media [12] therefore making the need for integration and assimilation of social media in research and education more evident.

It is difficult to imagine holding a college level class or any form of research today which does not explore the internet or social media in one way or another, either by the use of search engines, bookmarks or using blogs, conducting an online survey, emails or instant messaging, many Student may find it hard to express themselves in front of their professors or in the class but express themselves more on social media platforms.

Chen, Seilhamer, Luke, \& Bauer [13], in their study found out that $79 \%$ of the students report extensive use of social network and $62 \%$ reports extensive use of other social media tools, with these teachers/researchers need to utilize this high usage to their advantage by monitoring the usage behavior to serve as a direction or focus for their research or a guide as to how they plan their lesson.

\section{$3 \quad$ Aims}

The aim of this research is to provide a guide for teachers/researchers on the best way to use social media to enhance teaching and gained more student satisfaction, while trying to achieve this we will also measure the following:

- Teachers social media dependency

- Social media usage habits by teachers and researchers

- Factors limiting social media usage by teachers and researchers

- The effect of social media in education

- A number of social media account used by the teachers

- Is there any significant difference among the genders in using social media for education

- What do the teachers use social media mostly for?

\section{$4 \quad$ Literature review}

As indicated by Ayeni [14], teaching is a ceaseless procedure that includes achieving fascinating changes in learners using suitable techniques. Adunola [15] states that in the quest of getting fascinating changes in students, instructional methods employed by the instructors ought to be the best for the topic, besides, managing the instructional technique works effectively primarily when they fit learners' needs since each learner deciphers and reacts to questions differently. In that capacity, linking of instructional techniques to students' needs and favoured learning methods has a massive impact on students' academic performance.

Social media comprises of (a) social networking sites, such as Eba, Instagram and facebook, (b) media sharing sites, e.g YouTube, (c) creation and publishing tools, eg wikis, (d) aggregation and republishing through RSS feeds, and (e) remixing of content and republishing tools [16]. 
Social media has advanced into Tertiary Institution; in 2010/2011 a research on social media acceptance by the University of Massachusetts Dartmouth surveyed the then current trending usage of social media among accredited institutions in the United State and discovered that all the college and university under the scope uses it. According to data collected by Ofcom at the beginning of 2017, $66 \%$ of all grownups aged 16 above have a minimum of one social network account, although the report did not present a detailed information with regards to the figures by age group, yet, it will be sensible to expect that among those of college age, the rate could possibly be significantly higher. We realize that colleges and other instruction providers have reacted by expanding their utilization of social media advertisement to exhibit their courses and lure students, however would they, say they are reaping the full energy of the medium, to relate and discuss with those same students once they commence their studies? Do social media have a place to serve as an instructional tool or is it basically a disturbance? It appears that a few teachers are surely starting to take advantage of the potential gain of social media in education. Numerous school and societies have agreed to the fact that $75 \%$ of students confess to being on Twitter "always" (Source: TopUniversities.com) and are utilizing the micro-blogging site as a medium to share content, revitalize debates and provide answers to questions, where some went as far as setting up hashtags for their courses to make online discussion groups for their students. In fact, this is a procedure accepted by some instructors to incite more insightful reactions from students, the thought being that when they know their remarks can be read by their mates and not only their teacher they consider what to state, as well as give careful consideration to how they compose it and pay more attention to spelling and grammar.

Social media has the advantages of allowing students, researchers and people in general interact and communicate in ways that ignore institutional limits, to prove this In September 2012 students of journalism at northern Carolina agriculture and technical state university utilized cell phones and social media to cover convention in charlotte North Carolina, the course not just enabled the students to acquire constructive and great understanding of the work but also presented them with old and upcoming theories in communication and ideas related to social media in the modern world. Paul [17] stated that nowadays students, not only have to know how to use the current communication tools, but also possess a growing confidence from their angle on the way these communication tools can be used, he went on to cite convenience as the main reason why students wants' information technology in their classes [18].

Tobi, Ma'on, \& Ghazali [19] states the ubiquity of online social network undertook a research to find out if the use of social media has significance on both the social and mental strength of Malaysian students. The researchers recommend that it has positive influence on the health of the students. Krasnova, Hildebrand, Günther, Kovrigin, \& Nowobilska [20] also stated that social networking site usage can boost happiness of the user and also minimize depression, if envy is controlled [21]. It was also stated that social network usage can lower the self-esteem of the user [22]. 


\section{$5 \quad$ Relevant Works}

To show how importance of social media in providing information in this modern day, Coleman [23] suggests that information from social media should be accepted as primary sources, he went ahead to suggest that student and researchers should be encouraged to share first-hand information on social media, which leads to some universities launching a course using social media.

Smith \& Rhodes [24] in their work on social media use all graduates and undergraduate students enrolled in 2009 spring semester at Virginia Commonwealth University to answer the question, what are social media tools used for by school of education students? What specific purpose do they serve? Do the social media serve and do students believe educators should involve the use of social media in their classes? The result shows that students use social media in their classes and the results show that students report that instructors mostly use use video sharing websites, wikis and blogs but $47 \%$ that instructors don't use social media at all.

Tinti-Kane [25] a biology professor at the university of Wisconsin at Milwaukee limits students to 140 characters during test and when formulating hypothesis and conclusion because he believes using the 140 character's strength will force student to gather their thoughts and state clearly a hypothesis or a conclusion.

\section{$6 \quad$ Methodology}

\subsection{Organization}

The research work was organized in 3 phases:

Phase 1: Where data were collected from teachers with regards to how they use social media in their classrooms

Phase 2: Where we pilot test the methods (as suggested by the lecturers) of using social media in education, on the control group in teaching a course in multi-media development after which a questionnaire was given to the student to access the students satisfaction levels. Synonymously, the researchers' 9-point method of applying social media in education was applied to the experimental group to teach the same course and the same questionnaire was used to access the level of student satisfaction.

Phase 3: Where the results were compared.

\subsection{Setting}

The data collected was organized and used on the control group to see its effect and the researcher's methods were also used and the result compared and the course was conducted in a blended way were normal face-to-face was taken for two hours every week, Facebook group as well as whatsApp were also utilized. 


\subsection{Participant}

Participant I: In order to gather primary data form the lecturers, a stratified random sampling method was used, where 6 universities from Northern Cyprus form the strata. 60 lecturers from this universities were surveyed, 17 from Near East University (NEU), 10 from Eastern Mediterranean University (EMU), 10 from Cyprus International University (CIU), 9 from Girne American University (GAU), 7 from European University of Lefke (EUL) and 7 from University of Kyrenia (UK).

Participant II: For the purpose of this research, the second set of participants were categorized into two groups using random sampling technique, to enable the researchers apply the data collected from participant I above as well as the researchers design 9-point method.

Group A: The control group consisting of a total of 37 students from department of computer and instructional technology, Near East University Cyprus that registered for multi-media development course fall semester 201720 boys and 17 girls age range of $18-23$.

Group B: The experimental group which consist of 21 students from the same department and the same institution as the control group, with and age $18-22$, of which 12 are females and 9 are males.

\subsection{Instrument}

For the purpose of this research, the researchers developed two questionnaires an open-ended questionnaire for the lecturers and a closed ended questionnaire for students to access their level of satisfaction.

\subsection{The control class}

Here, we applied what the teachers report doing while teaching with social media groups were created to communicate with the students and assignments were submitted, slides were used and YouTube videos were also used.

\subsection{The experimental class}

Here, the researchers applied the 9 points method which according to them is the best way to use social media in classes, the methods classified according to how the methods operates and using social media terminologies, they are as follows;

Throwback lecture: is an hour where previous lectures were brought forward by the teacher, culled from instagram throw-back pictures, it is a time where the teachers called a topic that has been treated previously and the students discussed it in a whatsApp group it occurs once a week.

140 character magic: Using the idea of twitter and used by Tinti-Kane [25] is when questions are asked and students are expected to answer with a sentence having 140 characters or less. 
\#important terminology: This is where a \#tag will be initiated with a special terminology regarding the course and student writes what they understand with regards to the word.

Free period: Here the teachers relinquish his authority by moving out of the group and leaving the students alone to discuss what they understand about the class. This is based on the assumption that peers understand each other better and knows how best to explain context to other friend's.

The video challenge: Students are here, allowed to choose relevant topics make a short video and post it and the teacher review ask questions about what they understand after the student that post the video has expressed the aim and target of the video.

Administration Exchange: Here the teacher gives out the lead of the class to a specific student, but with a scope and limitation and also a topic to discuss, and the teacher becomes just like other students.

Free Posting: it's a period where students are allowed to post something that does not happen in the class, but should be educative even if not very relevant to the class, this might include wise words, motivational quotes, inspirational videos, e.t.c.

What is on your mind: Adopted from facebook, here, students are asked to post their view with regards to topics past, what they read from other sources regarding the topics (they are allowed to share videos and blog post etc, as support of their view), what they did not understand or needs clarification.

Trending topic: Here we considered the words that either many students did not understand and tried to make sure they understand them by continuos explanations and application till the students understand them.

\section{$7 \quad$ Analysis}

The average serving years of the lecturers is 6 years 2 months and the average number of accounts per lecturer is 4.8 which correspond to Mander, [26], whereas the average time spent on social media by the lecturers was 4 hours 10 minutes which contradicts Davidso [27] and Judging by the questionnaire, older lecturers depend less on social media than their young counterparts.

A mixed up in meaning between social media and social network was spotted. For instance, while answering the question "what are the types of social media tools do you use" most lecturers answers by using only the social networking sites but then when "answering how do you use it" a lot of the lecturers says through my YouTube channel although they didn't cite YouTube as the social media tool they use, another case was when a lecturer answers "do you use social media for education" some answers NO when ask "why don't you use it" his answer was "because I have other options like Google and YouTube" some site the reasons why they don't use social media in education as due to the reliability of the information received (which is mostly linked with social networks) while some lecturers report using social media only for chatting which can also only be linked with social networks. 
The use of social media that receive highest mention was passing information to students and communication whereas facebook was the highest used tool with facebook group creation having the highest patronage.

Most of the lecturers report using social media more on personal things, than education which corresponds to the findings of Tinti-Kane [25], a lecturer went on to say that he uses social media for personal learning but not for teaching.

Among the reason why they use social media in their classes where flexibility, ease in access, it's fun, idea sharing, for searching of educational materials and receiving or assigning assignment to students.

Despite all that was stated the researchers notice high dependency ratio of social media by the lecturers, but also found that majority complains about reliability of information, another factor worth note is the ethical issues regarding social media usages.

\section{$8 \quad$ Result and discussion}

Table 1. Descriptive Statistics for the Control Group

\begin{tabular}{|l|c|c|}
\hline & Mean & $\begin{array}{c}\text { Std. } \\
\text { Devia- } \\
\text { tion }\end{array}$ \\
\hline how do you feel with regards to the current teaching methodology & 3.6190 & .49761 \\
\hline How convenient have you been finding the classes & 3.4286 & .59761 \\
\hline How Flexible have you been finding the classes & 3.6190 & .58959 \\
\hline How can you rate your understanding of what is being taught in the class & 3.9524 & .74001 \\
\hline How would you feel if all your classes are to be conducted using the same process & 3.6667 & .73030 \\
\hline How would you feel if you are to continue learning using the procedure & 3.7143 & .78376 \\
\hline In your own opinion how would you rate the teaching method & 3.9048 & .83095 \\
\hline $\begin{array}{l}\text { How would you rate the contribution of your previous social media experience while } \\
\text { conducting this cours }\end{array}$ & 3.9524 & .92066 \\
\hline In your own opinion could a student with no social media experience enjoy the class & 3.3810 & 1.02353 \\
\hline In your opinion how would you rate the class if the teacher would be changed & 1.5714 & .92582 \\
\hline Valid N (listwise) & & \\
\hline
\end{tabular}

Two questions from the control group response to the satisfaction questionnaire, how would you rate the contribution of your previous social media experience while conducting this course and how can you rate your understanding of what is being taught in the class, synonymously, receive the highest response, with mean $(\mathrm{M})=$ 3.9524 in a class of 5 and standard deviation $(\mathrm{SD})=.92066$, which does not come as a surprise considering the fact that the course uses social media and that, the students report high social media usage and experience, which in turn helps them understand the course better, on the other hand, the question that report the lowest point was, in your opinion how would you rate the class, if the teacher would be changed, with $\mathrm{M}=$ $1.5714 \mathrm{SD}=.92582$ which shows the students are indifferent as to who teaches the class, so far the instrument remains the same, as can be seen in Table 1. Whereas, 
from the experimental group the question that has the highest score was how would you feel if all your classes are to be conducted using the same process with an average mean $(\mathrm{M})=4.4286$ and standard deviation $(\mathrm{SD})=.50709$ which might be attributed also to the high usage and number of hours spent on social media by the students, the question that receive the lowest point was in your opinion how would you rate the class if the teacher would be change with $\mathrm{M}=1.0952$ and $\mathrm{SD}=.30079$ which might be attributed to fear of not knowing who the next teacher might be as can be seen from Table 2.

Table 2. Descriptive Statistics for the Experimental Group

\begin{tabular}{|c|c|c|}
\hline & Mean & $\begin{array}{l}\text { Std. } \\
\text { Devia- } \\
\text { tion }\end{array}$ \\
\hline how do you feel with regards to the current teaching methodology & 4.0952 & .43644 \\
\hline How convenient have you been finding the classes & 4.1905 & .51177 \\
\hline How Flexible have you been finding the classes & 4.1905 & 60159 \\
\hline How can you rate your understanding of what is being taught in the class & 4.3333 & .65828 \\
\hline How would you feel if all your classes are to be conducted using the same process & 4.4286 & .50709 \\
\hline How would you feel if you are to continue learning using the procedure & 4.2857 & .64365 \\
\hline In your own opinion how would you rate the teaching method & 4.2857 & .64365 \\
\hline $\begin{array}{l}\text { How would you rate the contribution of your previous social media experience while } \\
\text { conducting this course }\end{array}$ & 4.0952 & .70034 \\
\hline In your own opinion could a student with no social media experience enjoy the class & 4.1429 & .79282 \\
\hline In your opinion how would you rate the class if the teacher would be changed & 1.0952 & .30079 \\
\hline Valid N (listwise) & & \\
\hline
\end{tabular}

The students shows high usage of social media with $51(87.9 \%)$ of the respondents saying they have more than 3 social media accounts which corresponds to Bicen \& Arnavut [28] and Nawaila \& Bicen [29] with only 7 (12.1\%) respondents having 3 or less accounts of social media, which is, also, in line with the world average number of social media accounts by international users [30], another factor worth note is the social media usage habits, the students shows high social media usage habit with 50 students, being social media for 2 hours or more daily, these also correspond to Bicen $\&$ Arnavut [28] which is above the world average of 2 hours [31].

A significant difference was found in the number of social media accounts between the genders where female respondents having an average of more than six, whereas their male counterpart stood at an average of 4- 6, but no significant difference was found between the genders with regards to time spent on social media.

No correlation was found between age and number of social media account, but, a significant negative correlation was found between age and time spent on social media at $r=-.462$ where $p=.035$ which can be interpreted as the lower the age of the student the higher his number of social media account, also, a significant positive correlation was found between the genders and how many social media accounts do you have at $r=.442$ where $\mathrm{p}=.045$. 
Table 3. showing number of social media accounts

\begin{tabular}{|l|l|c|c|}
\hline \multicolumn{2}{|l|}{} & Frequency & Percent \\
\hline \multirow{4}{*}{ Valid } & less than 4 & 7 & 12.1 \\
\cline { 2 - 4 } & $4-6$ & 34 & 58.6 \\
\cline { 2 - 4 } & greater than 6 & 17 & 29.3 \\
\cline { 2 - 4 } & Total & 58 & 100.0 \\
\hline
\end{tabular}

Table 4. showing the time spent on social media

\begin{tabular}{|l|l|c|c|}
\hline \multicolumn{2}{|l|}{} & Frequency & Percent \\
\hline \multirow{4}{*}{ Valid } & less than 2 hours & 6 & 10.3 \\
\cline { 2 - 4 } & $2-4$ & 41 & 70.7 \\
\cline { 2 - 4 } & greater than 4 & 11 & 19.0 \\
\cline { 2 - 4 } & Total & 58 & 100.0 \\
\hline
\end{tabular}

Table 5. showing T Test result on gender and number of social media account

\begin{tabular}{|c|c|c|c|c|c|c|c|c|}
\hline & \multicolumn{2}{|c|}{$\begin{array}{l}\text { Levene's test for } \\
\text { equality of variance }\end{array}$} & \multicolumn{5}{|c|}{ t-test for equality of means } \\
\hline & & $F$ & Sig & $T$ & $D f$ & $\begin{array}{c}\text { Sig. } \\
\text { (2-tailed) }\end{array}$ & $\begin{array}{c}\text { Mean } \\
\text { Difference }\end{array}$ & $\begin{array}{l}\text { Std. error } \\
\text { Difference }\end{array}$ \\
\hline \multirow{2}{*}{$\begin{array}{l}\text { How many } \\
\text { social media } \\
\text { account do } \\
\text { you have }\end{array}$} & $\begin{array}{l}\text { Equal variance } \\
\text { assumed }\end{array}$ & 1.443 & .244 & -2.151 & 19 & .045 & -.61111 & .28414 \\
\hline & $\begin{array}{l}\text { Equal variance } \\
\text { not assumed }\end{array}$ & & & -2.188 & 18.344 & .042 & -.61111 & .27929 \\
\hline
\end{tabular}

Table 6. showing correlations

\begin{tabular}{|c|c|c|c|c|c|}
\hline & & $\begin{array}{l}\text { What is } \\
\text { your } \\
\text { gender }\end{array}$ & $\begin{array}{l}\text { How old } \\
\text { are you }\end{array}$ & $\begin{array}{c}\text { How many social } \\
\text { media account do } \\
\text { you have }\end{array}$ & $\begin{array}{c}\text { How many hours do } \\
\text { you spent on social } \\
\text { media }\end{array}$ \\
\hline \multirow{3}{*}{$\begin{array}{l}\text { What is your } \\
\text { gender }\end{array}$} & Pearson Correlation & 1 & -.096 & .394 & -.121 \\
\hline & \begin{tabular}{|l|} 
Sig. (2-tailed) \\
\end{tabular} & & .680 & .077 & .602 \\
\hline & $\mathrm{N}$ & 58 & 58 & 58 & 58 \\
\hline \multirow{3}{*}{$\begin{array}{l}\text { How old are } \\
\text { you }\end{array}$} & Pearson Correlation & & 1 & -.398 & $-.513 *$ \\
\hline & \begin{tabular}{|l|} 
Sig. (2-tailed) \\
\end{tabular} & & & .074 & -.017 \\
\hline & $\mathrm{N}$ & & 58 & 58 & 58 \\
\hline \multirow{3}{*}{$\begin{array}{l}\text { How many } \\
\text { social media } \\
\text { account do you } \\
\text { have }\end{array}$} & Pearson Correlation & & & 1 & .320 \\
\hline & Sig. (2-tailed) & & & & .152 \\
\hline & $\mathrm{N}$ & & & 58 & 58 \\
\hline \multirow{3}{*}{$\begin{array}{l}\text { How many } \\
\text { hours do you } \\
\text { spent on social } \\
\text { media }\end{array}$} & Pearson Correlation & & & & 1 \\
\hline & \begin{tabular}{|l|} 
Sig. (2-tailed) \\
\end{tabular} & & & & \\
\hline & $\mathrm{N}$ & & & & 58 \\
\hline
\end{tabular}

*correlation is significant at the 0.05 level (2-tailed) 
Table 7. showing $\mathrm{T}$ Test result for the two methods

\begin{tabular}{|c|l|c|c|c|c|c|c|c|}
\hline \multicolumn{2}{|c|}{} & \multicolumn{2}{|c|}{$\begin{array}{c}\text { Levene's test for } \\
\text { equality of variance }\end{array}$} & \multicolumn{5}{|c|}{ t-test for equality of means } \\
\cline { 2 - 9 } \multicolumn{2}{|c|}{} & $\boldsymbol{F}$ & $\boldsymbol{S i g}$ & $\boldsymbol{T}$ & $\boldsymbol{d f}$ & $\begin{array}{c}\text { Sig. } \\
\text { (2-tailed) }\end{array}$ & $\begin{array}{c}\text { Mean } \\
\text { Difference }\end{array}$ & $\begin{array}{c}\text { Std. error } \\
\text { Difference }\end{array}$ \\
\hline Total & $\begin{array}{l}\text { Equal variance } \\
\text { assumed }\end{array}$ & .823 & .370 & -3.880 & 40 & .000 & -4.33333 & 1.11677 \\
\cline { 2 - 9 } & $\begin{array}{l}\text { Equal variance } \\
\text { not assumed }\end{array}$ & & & -3.880 & 37.920 & .000 & -4.33333 & 1.11677 \\
\hline
\end{tabular}

A significant difference was found on the level of satisfaction among students that took the normal methods used by the lecturers and those that took the researchers 9 point method, which can be attributed to the methodology of teaching which employ the use of social methods.

\section{Conclusion and recommendation}

The current number of social media platforms and their high usage among students is only going to get bigger considering the technological development and how these technologies always try to integrate social media, which is ever turning the current and the next trend of students to technological and social media addicts.

This research considers this addiction and the importance of knowledge to try to bring forth an idea on how to teach students using social media. The research founds high usage of both social media and time dedicated to social media among lecturers and students, the research also found out that students are more satisfied with the researcher's 9-point methods than the regular methods employed by their teachers because not only that is uses social media but it also adopt the current termination used by the students in their daily interactions which makes the class more attractive and fun.

The limitation of this research lies mostly on the number of samples used while conducting the research and the additional cost of internet that the students has to bear, therefore, for future work, we will recommend trying the methods on larger samples and on students with less social media usage and experience, we will also recommend accessing whether the method indeed improve retention and performance.

\section{References}

[1] Chaffey, D. (2017). Global social media research summary 2016. Retrieved March 17, 2017, from http://www.smartinsights.com/social-media-marketing/social-media-strategy/ new-global-social-media-research/?new $=1$

[2] Ala-Mutka, K., Redecker, C., \& Punie, Y. (2010). The Future of Learning: European Teachers' Visions. ... Consultation At the 2010 ..., (February), 5-7. Retrieved from ftp://ftp.jrc.es/users/publications/public/JRC59775 TN.pdf 
[3] Nations, D. (2016). What Is Social Media? Explaining the Big Trend. Retrieved February 10, 2017, from https://www.lifewire.com/what-is-social-media-explaining-the-big-trend3486616

[4] Nada, D., \& Rick, R. (2011). Back to the Furture: Tracing the Roots and Learning Affordances of Social Software. Web 2.0-based E-learning: Applying Social Informatics for Tertiary Teaching. https://doi.org/10.4018/978-1-60566-294-7

[5] Smith, M. K. (2016). "What is teaching?" in the encyclopaedia of informal education. Retrieved March 3, 2017, from http://infed.org/mobi/what-is-teaching/

[6] Tebabal, A., \& Kahssay, G. (2011). The Effects of Student-Centered Approach in Improving Students' Graphical Interpretation Skills and Conceptual Understanding of Kinematical Motion. Latin American Journal of Physics Education, 5(2), 374-381.

[7] Hudson-Ross, S., \& McWhorter, P. (1996). Going Back / Looking In : A Teacher Educator and a High School Teacher Explore, 84(2), 46-54.

[8] Hesson, M., \& Shad, K. F. (2007). A student-centered learning model. American Journal of Applied Sciences, 628-636. https://doi.org/10.3844/ajassp.2007.628.636

[9] Lindquist, T. M. (1995). Traditional versus contemporary goals and methods in accounting education: Bridging the gap with cooperative learning. Journal of Education for Business, 70(5), 278-284. https://doi.org/10.1080/08832323.1995.10117764

[10] Slavin, R. (1996). RESEARCH FOR THE FUTURE Research on Cooperative Learning and Achievement : What We Know, What We Need to Know. Contemporary Educational Psychology, 69(1), 43-69. https://doi.org/10.1006/ceps.1996.0004

[11] Fill, C. (2011). Essentials of marketing communications. Harlow: Pearson Educational Limited.

[12] Dron, J. (2007). Designing the undesignable: Social software and control. Educational Technology \& Society, 10(3), 60-71.

[13] Chen, B., Seilhamer, R., Luke, B., \& Bauer, S. (2015). Students' Mobile Learning Practices in Higher Education: A Multi-Year Study. Retrieved March 15, 2017, from https://er.educause.edu/articles/2015/6/students-mobile-learning-practices-in-highereducation-a-multiyear-study

[14] Ayeni, A. J. (2011). Teachers' Professional Development and Quality Assurance in Nigerian Secondary Schools. World Journal of Education, 1(2), 143-149. https://doi.org/10.5430/wje.v1n2p143

[15] Adunola, O. (2011). The Impact of Teachers' Teaching Methods on the Academic Performance of Primary School Pupils in Ijebu-Ode Local cut Area of Ogun State, , ,. Ogun State, Nigeria.: Ego Booster Books.

[16] Greenhow, C. (2011) Youth, Learning, and Social Media. Journal of Educational Computing Research Vol 45, Issue 2, pp. 139 - 146 https://doi.org/10.2190/EC.45.2.a

[17] Paul, H. (2001). Interesting practices and best systems in faculty engagement and support final report to the national learning infracture initiave. Lefkosia.

[18] Nawaila, M.B., Ozamli, F. \& Kanbul, S. (2017). Amobile application for a multimedia development course: CEITech. Ponte Journal 73(6)

[19] Tobi, S., Ma'on, S., \& Ghazali, N. (2013). The Use of Online Social Networking and Quality of Life. Technology, Informatics, Management, Engineering, and Environment (TIME-E), 2013 International Conference on, 131-135 Krasnova, H., Hildebrand, T., Günther, O., Kovrigin, A., \& Nowobilska, A. (2008). Why Participate in an Online Social Network: an Empirical Analysis. Network, 2124-2135. https://doi.org/10.1111/j.13652575.1996.tb00021.x

[20] Krasnova, H., Hildebrand, T., Günther, O., Kovrigin, A., \& Nowobilska, A. (2008). Why Participate in an Online Social Network: an Empirical Analysis. Network, 2124-2135. https://doi.org/10.1111/j.1365-2575.1996.tb00021.x 
[21] Tandoc, E. C., Ferrucci, P., \& Duffy, M. (2015). Facebook use, envy, and depression among college students: Is facebooking depressing? Computers in Human Behavior, 43, 139-146. https://doi.org/10.1016/j.chb.2014.10.053

[22] Błachnio, A., Przepiórka, A., \& Pantic, I. (2015). Internet use, Facebook intrusion, and depression: Results of a cross-sectional study. European Psychiatry, 30(6), 681-684. https://doi.org/10.1016/j.eurpsy.2015.04.002

[23] Coleman, V. (2013). Social Media as a Primary Source : Educause Review, 48(6), 60-61. https://doi.org/10.1080/13688804.2014.950639

[24] Smith, F. \& Rhodes, A. J. (2010). Academic and personal use of social media. Retrieved from https://www.youtube.com/user/VCUSOE

[25] Tinti-Kane, H. (2013). Overcoming Hurdles to Social Media in Education. Retrieved February 12, 2017, from https://er.educause.edu/articles/2013/4/overcoming-hurdles-to-socialmedia-in-education

[26] Mander, J. (2015). Internet Users Have Average of 5.54 Social Media Accounts. Retrieved March 27, 2017, from https://blog.globalwebindex.net/chart-of-the-day/internetusers-have-average-of-5-54-social-media-accounts/

[27] Davidso, L. (2015). Is your daily social media usage higher than average? Retrieved April 20, 2017, from https://www.telegraph.co.uk/finance/newsbysector/mediatechno logyandtelecoms/11610959/Is-your-daily-social-media-usage-higher-than-average.html

[28] Bicen, H., \& Arnavut, A. (2015). Determining the effects of technological tool use habits on social lives. Computers in Human Behavior, 48, 457-462. https://doi.org/10.1016/ j.chb.2015.02.012

[29] Nawaila, M.B. \& Bicen, H. (2018). WhatsApp as a tool for distance learning. Ponte Journal 74(1) https://doi.org/10.21506/j.ponte.2018.1.36

[30] SMITH, K. (2017). 105 Amazing Social Media Statistics and Facts. Retrieved December 29, 2017, from https://www.brandwatch.com/blog/96-amazing-social-media-statistics-andfacts-for-2016/

[31] Statista.com. (2017). Minutes), Daily time spent on social networking by internet users worldwide from 2012 to 2017 (in. Retrieved May 5, 2017, from https://www.statista.com/ statistics/433871/daily-social-media-usage-worldwide/

[32] Garcia Laborda, J., Magal Royo, T. \& Bakieva, M. (2016). Looking towards the Future of Language Assessment: Usability of Tablet PCs in Language Testing. Journal of Universal Computer Science 22(1), 114-123.

\section{Authors}

Muhammad Bello Nawaila is a Nigerian currently undergoing his $\mathrm{PhD}$ at the department of computer education and instructional technology of Near East University, North Cyprus interested in the application of social media to education and children internet usage.

Sezer Kanbul is a Cypriot and an Assit. Prof. at Near East University, North Cyprus with skills and expertise in e-learning, technology enhanced learning, computer in education and distance learning.

Huseyin Uzunboylu is a Cypriot and an Associate Prof. and the vice dean distance learning center at Near East University, North Cyprus with skill and expertise in teaching and learning, pedagogy and education as well as teacher training.

Article submitted 10 June 2018. Resubmitted 15 July 2018. Final acceptance 09 August 2018. Final version published as submitted by the authors. 